\title{
Estimation of genetic parameters for measures of calf survival in a population of Holstein heifer calves from a heifer-raising facility in New York State
}

\author{
L. Henderson, ${ }^{\star}$ F. Miglior, $\nmid{ }^{1}$ A. Sewalem, $† \ddagger$ D. Kelton, ${ }^{\star}$ A. Robinson,§ and K. E. Leslie* \\ *Department of Population Medicine, University of Guelph, Guelph, Ontario, N1G 2W1, Canada \\ †Guelph Food Research Centre, Agriculture and Agri-Food Canada, Guelph, Ontario, N1G 5C9, Canada \\ ¥Canadian Dairy Network, Guelph, Ontario, N1K 1E5, Canada \\ §Department of Animal and Poultry Science, University of Guelph, Guelph, Ontario, N1G 2W1, Canada
}

\begin{abstract}
The objectives of this study were to estimate the genetic parameters of survival to weaning and survival to exit for a population of Holstein calves from New York State, as well as to associate the estimated breeding values determined in the current study with traits from ongoing genetic evaluations used in Canada and the United States. Data were recorded for 7,372 heifer calves at a commercial rearing facility in New York State from arrival at 1 to $7 \mathrm{~d}$ of age for the duration of stay at the facility (on average, heifers departed the facility 1 mo before calving). Performance and disease up to weaning and mortality before and after weaning were recorded. Analyzed data were limited to daughters of sires with at least 10 calves originating from farms that had sent a minimum of 5 calves to be raised at the facility. As such, calves from 264 sires and 36 herds were studied using 2 statistical methods. The first method, calf survival, used a Weibull proportional hazards model, with survival defined as age at culling, death, or censoring. The second method, a 2-trait sire model, included survival from arrival to weaning (SUV1) and survival from weaning to exit (SUV2). Both models included fixed effects of arrival weight, serum total protein, weaning weight, season and year of birth, and calving ease score. Herd and sire were included as random effects. Significant associations among all fixed effects and calf survival were observed. In general, very light or heavy weight at arrival, low total protein, low weaning weight, and difficult birth increased risk of mortality for calves. The heritability of survival from the first method was 0.063. The heritabilities from the linear model were 0.001 for SUV1 and 0.036 for SUV2. The genetic correlation between SUV1 and SUV2 was 0.58. Genetic variance was close to zero for survival of calves to weaning, but was greater for survival after weaning through the growing period. Breeding values were estimated for
\end{abstract}

Received March 9, 2010.

Accepted July 26, 2010.

${ }^{1}$ Corresponding author: miglior@cdn.ca
SUV1 and SUV2 and correlated with routinely evaluated traits from Canadian and US genetic evaluations. Significant associations between genetic evaluations for survival traits and routinely evaluated traits in Canada and the United States were found, in particular with conformation body traits, somatic cell score, fertility, and longevity.

Key words: calf survival, variance component estimation, multiple-trait model

\section{INTRODUCTION}

Genetic selection for improved health and longevity is a major goal of dairy cattle breeders. However, little attention has been paid to the genetic components of calf and heifer survival. Death of youngstock represents a recurring concern among breeders of dairy cattle in Canada and the United States. Currently, Canada and the United States genetically evaluate mortality only for the first 24 and $48 \mathrm{~h}$ of life, respectively, a trait also known as "stillbirth" (Philipsson et al., 1979; Berger et al., 1998). Furthermore, stillbirth is recorded exclusively on a voluntary basis in both countries, resulting in highly variable recording of stillbirths from farm to farm. Calf and heifer losses in the United States were recently estimated as $9.6 \%$ mortality each year, with unweaned heifers accounting for $7.8 \%$ and heifers from weaning to calving age accounting for $1.8 \%$ (NAHMS, 2007). Previous research has shown that the most common causes of preweaning mortality are gastrointestinal diseases (e.g., scours) and the most common cause of postweaning mortality is undifferentiated bovine respiratory disease (Sivula et al., 1996; Svensson et al., 2006; Gulliksen et al., 2009). The difference in susceptibility at different ages may indicate that different genes are responsible for pre- and postweaning mortality, a genetic attribute of mortality that has been previously speculated by Hansen et al. (2003). The effects of calf and heifer mortality are substantial from the economic, genetic, and animal welfare points of view. Costs include the loss in value of the calf and the genetic loss, which is rather hard to quantify, because genetic gains 
accrue over generations. Many studies have investigated environmental influences and their effects on calf mortality (Waltner-Toews et al., 1986; Curtis et al., 1988; Sivula et al., 1996; Wells et al., 1996). A limitation with these studies is that environmental factors are dynamic (i.e., management and housing) and they are generally not permanent. In contrast, the improvement of the additive genotype of calves would be permanent and cumulative across generations. For this improvement to occur, additive genetic variation for mortality needs to exist. In a review of selection for disease resistance by Shook (1989), it was concluded that more genetic and economic studies on calfhood mortality are needed before making decisions on the use of this trait in breeding programs. To date, few genetic studies of calf mortality have been carried out, and these efforts have examined primarily preweaning mortality (Cundiff et al., 1986; Erf et al., 1990; Hansen et al., 2003). The objectives of the current study were to estimate genetic parameters for survival to weaning and survival to exit for a population of calves from New York State, as well as to associate EBV for the 2 calf survival traits with traits routinely evaluated in Canada and United States.

\section{MATERIALS AND METHODS}

\section{Rearing Process at the Commercial Heifer-Raising Facility}

The commercial heifer-raising facility that participated in this investigation is located in western New York State. The farm raises Holstein heifers to varying target ages based on the contractual arrangement between the facility and the farm of origin. At any given point, approximately 4,000 calves are housed at the facility. Heifer calves typically arrive at the facility in the first 2 to $3 \mathrm{~d}$ of life, with a small number of calves arriving at up to $1 \mathrm{wk}$ of age. Upon arrival, calves are weighed, measured, and identified with a unique ear tag number, which corresponds to the DairyComp 305 (ValleyAg Software, Tulare, CA) data for the facility. In addition, calves are sampled for serum total protein (TP) levels to assess passive transfer of immunity and to provide a basis for contractual warranties of calf survival. No guarantees of survival are made for the first $12 \mathrm{~d}$ of life or if the heifer calf enters the facility with a TP score of $\leq 53 \mathrm{~g} / \mathrm{L}$. If heifers enter the facility with a TP score of 54 to $59 \mathrm{~g} / \mathrm{L}$, the heifer-raising farm shares any treatment or death losses with the herd of origin. For calves with a TP score of $60 \mathrm{~g} / \mathrm{L}$ or higher, the facility refunds all fees and medication for any calf that dies. Calves were reared in individual pens in barns of 48 calves, and were weaned at approximately $7 \mathrm{wk}$ of age using a step-down method, during the study period.
On the Monday following weaning, calves were moved to the weaning barn and grouped for the first time. For each heifer, the information recorded in DairyComp 305 included source farm of origin, calving ease, birth date, sire, maternal grandsire (if provided), arrival date, arrival weight and height, serum TP, disease treatments during the preweaning period, weaning date, weaning weight and height, death, and culling occurrences. Heifers were raised on site until approximately 1 mo before calving, at which point they were sent back to their source farm of origin.

\section{Data Description and Editing}

DairyComp 305 archives from December 1998 to June 2008 were obtained from the participating heifer-raising facility. Data consisted of records from 14,629 heifer calves from 38 herds sired by 502 bulls. Records with missing sire identification, unidentified source farm of origin, calves that arrived older than 1 wk of age, calves with incorrect weaning dates, and duplicate records were excluded from the analysis (data set reduced to 13,694 heifer calves). Restriction criteria placed on the data permitted heifers to be included in the analysis only if they were sired by a bull that had at least 10 daughters in the database, and from source farms that had sent a minimum of 5 calves to be raised at the facility. After all editing, the data for analysis consisted of 7,372 calf records from 36 herds sired by 264 bulls.

\section{Methods of Analyses}

Calf survival was analyzed using a survival analysis with a Weibull proportional hazards model and a linear multiple-trait analysis. Details of each procedure are described below.

Survival Analysis. In this procedure, length of a calf's life was defined as time (in days) from arrival at the heifer-raising farm until death; otherwise, the record was censored if the calf had left the farm to return to its source farm of origin. A lifetime record was considered completed (uncensored) if the calf received a termination code (i.e., death), indicating that the calf or heifer was culled or died for any reason.

The following model was used:

$$
\lambda(t)=\lambda_{0}(t) \exp \left\{\mathbf{x}_{\mathbf{m}}{ }_{\mathbf{m}}(t) \beta+\mathbf{z}_{\mathbf{m}} \mathbf{u}\right\},
$$

where $\lambda(t)$ is the hazard function for calf survival; that is, the probability of dying at time $t$ given the calf survived up to time $t-1 ; \lambda_{0}(t)=\lambda \rho(\lambda t)^{\rho-1}$ is the Weibull baseline hazard function with scale parameter $\lambda$ and shape parameter $\rho$, and $t$ is the time from arrival at the facility; $\beta$ contains covariates affecting the haz- 
ard with $\mathbf{x}_{\mathbf{m}}(t)$ being the corresponding design vectors and $\mathbf{u}$ the vector of random variables with associated incidence vector $\mathbf{z}_{\mathbf{m}}$. The fixed variables in the model included arrival weight class (defined as $1=22-33 \mathrm{~kg}$; $2=34-37 \mathrm{~kg} ; 3=38-41 \mathrm{~kg} ; 4=42-46 \mathrm{~kg} ; 5=47 \mathrm{~kg}$ and above); weaning weight class $(1=34-50 \mathrm{~kg} ; 2=$ $51-59 \mathrm{~kg} ; 3=60-68 \mathrm{~kg} ; 4=69-80 \mathrm{~kg} ; 5=81-126 \mathrm{~kg}$ ); total protein class (defined as $1=30-49 \mathrm{~g} / \mathrm{L} ; 2=50-59$ $\mathrm{g} / \mathrm{L} ; 3=60-69 \mathrm{~g} / \mathrm{L} ; 4=70-80 \mathrm{~g} / \mathrm{L}$ ); season of birth class (seasons were January to March, April to June, July to September, and October to December); calving ease score (defined as $1=$ unobserved/unassisted, $2=$ easy pull, $3=$ hard pull, and $4=$ excessive force or surgery needed); disease incidence class (defined as $0=$ no disease experienced, $1=$ disease occurrence, $2=2$ disease occurrences, $3+=3$ or greater disease occurrences); and, finally, source farm of origin. The random effects included the effect of herd-year class, assumed to follow a log gamma distribution with mean zero and variance $\sigma_{\text {hys }}^{2}$ and the additive genetic effect of the sire of the calf, which was assumed to follow a multivariate normal distribution with mean zero and variance $\mathbf{A} \sigma_{s}^{2}$, where $\sigma_{s}^{2}$ is sire variance and $\mathbf{A}$ is the relationship matrix. A sire variance of 0.098 was used in the analyses as estimated using the above model. Using a Weibull proportional hazards model, the analyses were performed with the Survival Kit software Version 5.1 (Ducrocq and Sölkner, 1998). Heritability was calculated as $h^{2}=4 \sigma_{s}^{2} /\left(1+\sigma_{\text {hys }}^{2}+\sigma_{s}^{2}\right)$ (Yazdi et al., 2002).

Linear Model. Survival of calves from arrival date to weaning (SUV1) and from weaning to exit from the heifer-raising facility (SUV2) were analyzed using a multiple-trait linear sire model. Survival in each of the 2 time periods (survival to weaning, and survival from weaning to exit) was considered to be separate. The following model was used for genetic parameter estimation,

$$
Y_{i j k l m}=h y_{i}+W_{j}+P_{k}+S_{l}+\text { sire }_{m}+e_{i j k l m},
$$

where $Y_{i j k l m}=$ observation for survival (0 or 1 ) in each trait, $h y$ is the random effect of herd-year of birth, $W$ is the fixed effect of arrival weight with 5 classes for SUV1 $(1=22-33 \mathrm{~kg} ; 2=34-37 \mathrm{~kg} ; 3=38-41 \mathrm{~kg} ; 4=$ $42-46 \mathrm{~kg} ; 5=47 \mathrm{~kg}$ and above) and weaning weight for SUV2 with 5 classes $(1=34-50 \mathrm{~kg} ; 2=51-59 \mathrm{~kg} ; 3=$ $60-68 \mathrm{~kg} ; 4=69-80 \mathrm{~kg} ; 5=81-126 \mathrm{~kg}), P$ is the fixed effect of total protein with 4 classes $(1=30-49 \mathrm{~g} / \mathrm{L} ; 2$ $=50-59 \mathrm{~g} / \mathrm{L} ; 3=60-69 \mathrm{~g} / \mathrm{L} ; 4=70-80 \mathrm{~g} / \mathrm{L}), S$ is the fixed effect for season of birth (seasons were January to March, April to June, July to September, and October to December), sire is the random additive genetic effect of sire of calf, and $e$ is the random effect of residual.
In matrix form, the multiple-trait sire model can be described as

$$
\mathbf{Y}=\mathbf{X b}+\mathbf{Z}_{1} \mathbf{h y}+\mathbf{Z}_{2} \mathbf{a}+\mathbf{e},
$$

where $\mathbf{Y}$ is the matrix of the observations for the 2 traits; $\mathbf{X}, \mathbf{Z}_{1}$, and $\mathbf{Z}_{2}$ are the incidence matrices relating the observations to the fixed and random herd-year and sire effects, respectively; $\mathbf{b}$ is a vector of fixed effects (including arrival weight group for SUV1 and weaning weight group for SUV2, total protein group and season of birth); hy is the vector of random herd-year effects; $\mathbf{a}$ is the vector of random genetic effects of sire of calf; and $\mathbf{e}$ is the vector of random residual effects. The expectations and assumed variance are $\mathbf{E}(\mathbf{y})=\mathbf{X b}$; $\mathbf{E}(\mathbf{h y})=\mathbf{E}(\mathbf{a})=\mathbf{E}(\mathbf{e})=0 ; \mathbf{V}(\mathbf{h y})=\mathbf{H Y} ; \mathbf{V}(\mathbf{a})=\mathbf{G}$; $\mathbf{V}(\mathbf{e})=\mathbf{R} ; \operatorname{cov}\left(\mathbf{a}, \mathbf{e}^{\prime}\right)=0$; and $\mathbf{V}(\mathbf{Y})=\mathbf{Z G Z}+\mathbf{H Y}$ $+\mathbf{R}$, where $\mathbf{H Y}$ is the direct product of an identity matrix (I) of order of the number of herd-years and the matrix of herd-year variances $\left(\mathbf{I} \otimes \mathbf{h y}_{\mathbf{0}}\right) ; \mathbf{G}$ is the direct product of the numerator relationship matrix (A) for sires and the matrix of genetic variance and covariances $\left(\mathbf{A} \otimes \mathbf{G}_{0}\right) ; \mathbf{R}$ is the direct product of an identity matrix of order of the number of observations and the matrix of error variances and covariances $\left(\mathbf{I} \otimes \mathbf{R}_{\mathbf{0}}\right)$. Heritability values were calculated as

$$
h^{2}=4 \sigma_{\text {sire }}^{2} /\left(\sigma_{\text {sire }}^{2}+\sigma_{h y}^{2}+\sigma_{e}^{2}\right) .
$$

(Co)variance components were estimated using REML implemented in the DMU software package with an expectation-maximization (EM) algorithm multivariate mixed model analysis (Madsen and Jensen, 2006).

\section{Estimation of Breeding Values}

Genetic parameters obtained from the linear model were used for the breeding values estimation procedure. Sire EBV obtained from the multiple-trait linear sire model were used for correlation analyses with other EBV or PTA for traits of economics importance obtained from the national genetic evaluation of Canada (performed by Canadian Dairy Network, Guelph, ON, Canada) and the United States (performed by Animal Improvement Programs Laboratory of USDA, Beltsville, MD, and by Holstein USA, Brattleboro, VT). Details of routine genetic evaluation in both Canada and the United States can be found at the Interbull Web site (Interbull, 2009).

For correlations with US traits, multi-trait acrosscountry evaluations (MACE) on the US scale (analyzed by Interbull) were used. The MACE PTA from the US scale for calving traits (direct and maternal 
Table 1. Descriptive statistics

\begin{tabular}{lc}
\hline Item & Amount \\
\hline Calves (n) & 7,372 \\
Sires (n) & 264 \\
Source farms of origin (n) & 36 \\
Days from arrival to weaning (d) & \\
Average & 47.3 \\
SD & 8.6 \\
Average death before weaning (\%) & 2.70 \\
Total protein (g/L) & 60.47 \\
Average & 8.00 \\
SD & 8.67 \\
Average death after weaning (\%)
\end{tabular}

calving ease, direct and maternal stillbirth) have been multiplied by -1 , so values are expressed in the same direction as Canadian calving EBV (i.e., higher values are desirable). For this reason, the US trait "stillbirth" will be labeled as "calf survival" for the remainder of this paper.

\section{RESULTS AND DISCUSSION}

As described in Table 1, of the 7,372 heifers included in the analysis, $2.70 \%$ died before weaning and $8.67 \%$ died after weaning, with a total of $11.37 \%$ removed by death or being culled before returning to their source farm of origin. This result is unusual because the preweaning period is when most death normally occurs in heifers (NAHMS, 2007). Mortality rates in the current study may have a different distribution because of housing practices at this facility, where calves were kept individually and were very closely monitored throughout the preweaning period. After weaning, calves are placed in larger groups in barns with loose housing pens. Typically at this point, calves that struggled with health issues through the preweaning period experience further and more serious health issues, subsequently increasing the postweaning mortality rate. Calves are kept in the weaning barn for an average of $47.3 \mathrm{~d}$ from arrival to weaning. Although each individual source farm can structure a specific time for return of their calves, most heifers return to their source farm of origin approximately 1 mo before calving. Because calves generally arrived at the facility as early as 1 to $2 \mathrm{~d}$ of age, some of the deaths occurring shortly after arrival may be categorized as stillbirth (according to the 48-h period used to define this trait in the United States). Previous research has reported that $11 \%$ of parturitions in primiparous Holstein cows and $5.7 \%$ in multiparous animals result in a stillborn calf (Meyer et al., 2001). Therefore, the cost of mortality in terms of replacement stock may be higher, on average, than the cost of mortality due to stillbirth.

\section{Survival Analysis}

The sire variance was estimated to be 0.098 along with a herd-year variance of 5.1481, yielding a heritability estimate of 0.063 . The fixed effect solutions were all expressed as relative mortality risks, defined as the ratio between estimated risk of mortality under the influence of certain environmental factors $\left[\exp \left(\beta_{\mathrm{i}}\right)\right.$ for level i] and the average risk (or reference risk), which is usually set to $1\left(\beta_{\mathrm{i}}=1\right)$. Values $>1$ indicate higher mortality risk associated with that environmental factor. Relative mortality risks $<1$ indicate lower culling risks (i.e., increasing effect of environmental factor on survival). For example, if the relative mortality risk for a given class is 2 , a calf in that class has twice the risk of dying compared with a calf in the reference class for that effect. Conversely, if the relative mortality risk for a given class is 0.5 , then a calf in that particular class has a $50 \%$ less chance of dying than a calf in the reference class.

Calving ease score, arrival weight, weaning weight, and disease incidence class were important fixed effects for the prediction of survival from arrival to exit. To a lesser extent, serum TP and season of birth also influenced survival to exit in this data set. Figures 1a to $1 \mathrm{f}$ show the relative risk ratios of mortality, from arrival to exit, for all fixed effects apart from source farm of origin and year of birth. Weaning weight class had the greatest influence on mortality risk (Figure 1d). The relative mortality risk for heifers that weighed between 34 and $50 \mathrm{~kg}$ at weaning was 3.17 times greater than a heifer who weaned at an average weight of 60 to $68 \mathrm{~kg}$. Conversely, heifers that weaned in the heaviest weaning weight class (81-126 kg) were approximately $40 \%$ more likely to survive than heifers who weaned in the average weaning weight class. This trend indicates that heifers with greater weaning weights are more likely to survive to maturity than heifers with average or lesser average weaning weights. Greater weaning weights could be attributed to a combination of less disease occurrence experienced throughout the preweaning period, as well as having genes for increased growth and general disease resistance. Reduced intake during illness and increased energy expenditure caused by morbidity can significantly affect the ability of a calf to grow (Van Amburgh, 2008). Furthermore, it has been hypothesized that a general disease resistance factor with a genetic component exists (Heringstad et al., 2008). The potential existence of enhanced resistance to disease in the group of heavier weaned heifers may have not only allowed them to wean at an increased BW, but also allowed these calves to have increased disease resistance in the postweaning period, decreasing 

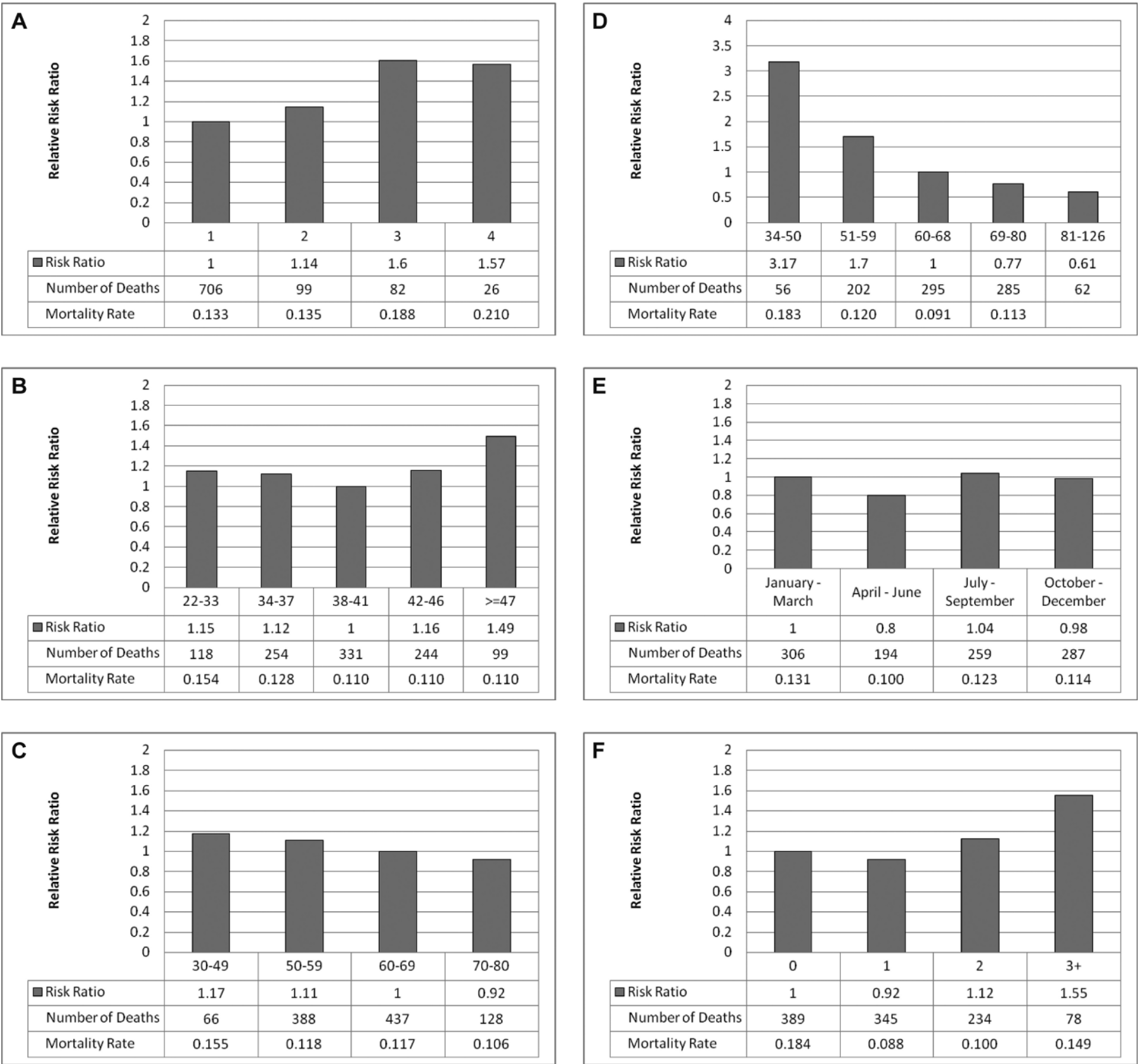

Figure 1. Risk ratio of removal (mortality and culling) for a) calving ease score; b) arrival weight class (kg); c) total protein (g/L) class; d) weaning weight $(\mathrm{kg})$ class; e) season of birth; and f) disease group class.

their susceptibility to illness and increasing their rate of survival to exit.

Calving ease score and arrival weight also influenced the risk of mortality before exit. As seen in Figure 1a, heifers with increasing calving ease score were more likely to die. However, the risk difference between a score of 3 and 4 was negligible. The negligible difference for risk of mortality between these 2 scores likely indicates that the same amount of distress and physical trauma is experienced by calves born to parturitions with a difficulty score of both 3 and 4 . Consistent with the literature, as calving difficulty increases, calf survival decreases. However, this has generally been documented considering calf survival during only the first 24 or $48 \mathrm{~h}$ of life (Meyer et al., 2001; Johanson and Berger, 2003). One study (Lombard et al., 2007) that examined survival beyond the first $2 \mathrm{~d}$ of life defined severe dystocia as "any calving with required assistance" and 
was associated with increased stillbirths and deaths up to $30 \mathrm{~d}$ of age. The latter study, as well as the current investigation, provide evidence that the effects of calving difficulty influence survival beyond the first $30 \mathrm{~d}$ of life, through to heifer maturity.

In the current study, arrival weight should closely reflect the birth weight of the calf (as most calves arrive at this heifer-raising facility in the first $2 \mathrm{~d}$ of life). Arrival weight also influenced the risk of mortality before exit. As seen in Figure 1b, there appeared to be an optimal arrival weight class $(38-41 \mathrm{~kg})$. Calves arriving in the 2 weight classes below optimal $(22-33 \mathrm{~kg}$ and $34-37 \mathrm{~kg})$ and 1 weight class above optimal (42-46 kg) were 15,12 , and $16 \%$ more likely to die before exit, respectively. The arrival weight group with the highest risk for mortality before exit was that with calves at $\geq 47 \mathrm{~kg}$. This result is to be expected because heavier calves usually experience more difficult in parturition (Linden et al., 2009), and as a result, have more health issues in early life (Lombard et al., 2007), increasing the risk of mortality.

Risk ratios were determined for disease incidence groups, and found to considerably affect survival to exit (Figure 1f). For instance, calves experiencing 2 or $\geq 3$ disease occurrences requiring treatment before weaning were 1.12 and 1.55 times, respectively, more likely to die before exit than calves that experience no preweaning disease. Interestingly, having been treated for one disease problem before weaning appeared to be protective, reducing the risk ratio to 0.92 for this group. This is likely because of the aggressive first treatment protocol in place at the heifer-raising facility, where calves were treated when displaying any minor sign of illness. The number of calves in this disease occurrence group is therefore very large. In retrospect, a large number of the calves in the disease occurrence group 1 might have not needed treatment. It is very likely that in a typical dairy herd situation, many of these calves would not have been treated. At this particular heifer-raising facility, however, because of the significant financial incentives in place, a rigorous first treatment protocol is the norm to ensure calves make it through the weaning process. The calves who received 1 treatment were more likely to survive to maturity than calves receiving no treatments, because this first treatment ensured speedy recovery from any illness that might have been present. Calves in disease treatment group 2 or $\geq 3$ had multiple signs of illness at different times, indicating that these calves were actually sick for an extended period, increasing their chances of dying.

To a lesser extent, serum TP group and season of birth affected risk of mortality before exit. As TP score increased, risk of mortality decreased, as seen in Figure 1c. This result was expected, because failure to absorb adequate amounts of immunoglobulins is known to be associated with higher rates of morbidity and mortality (McGuire et al., 1976; Robison et al., 1988; Donovan et al., 1998). A Florida study demonstrated that calves with low TP values $(<50 \mathrm{~g} / \mathrm{L})$ are 3 to 6 times more likely to die within the first 6 mo of life compared with those with serum TP concentrations of $>60 \mathrm{~g} / \mathrm{L}$ (Donovan et al., 1998). The serum TP results in the current study did not affect survival to the degree reported in the previously mentioned Florida study. However, a positive relationship of high serum TP upon arrival with survival to exit does exist. In the current study, the reduced influence of serum TP on survival is most likely because of the incentives in place at the heiferraising facility for calves that arrive at the facility with a score of $54 \mathrm{~g} / \mathrm{L}$ or higher. As a result, $82.2 \%$ of calves achieve this level, thereby reducing the proportion of calves with low serum TP. These incentives most likely entice source-farm producers to have proper colostrum management and delivery techniques in place to ensure that their calves receive a passing score on arrival at the heifer-raising facility.

In terms of season of birth, risk of mortality after weaning was not highly variable between the 4 seasons. However, a slight protective effect was observed for calves being born in the spring versus calves born in the summer (Figure 1e).

\section{Linear Model Analysis}

Variance components were estimated by fitting the model described by equation [2] to the data set described in Table 1. Estimates of sire, herd-year, residual, and total variances for each of the 2 survival traits are provided in Table 2. Herd-year variance and sire variance were equal and close to zero for SUV1 $\left(\sigma_{s}^{2}=\sigma_{h y}^{2}=\right.$ $0.0000009)$. However, for SUV2, herd-year variance $\left(\sigma_{h y}^{2}\right.$ $=0.0017254)$ was a much larger component of the total variance $(0.0792898)$ than sire variance $\left(\sigma_{s}^{2}=0.0007028\right)$. Estimates of heritabilities, genetic correlations, and residual correlation are shown in Table 3 . The heritability estimate for SUV2 $\left(h^{2}=0.036\right)$ was found to be much greater than that for SUV1 $\left(h^{2}=0.0006\right)$. The survival analysis was expected to result in a higher heritability estimate than that obtained from the linear analysis, which was the case. Heritability of preweaning and postweaning mortality has previously been reported for European calf populations. However, these heritability estimates have not been reported for a North American Holstein population. Hansen et al. (2003) estimated genetic parameters of postnatal mortality in Danish Holstein calves using a linear sire model. One of the binary traits considered by these authors was death 
Table 2. Sire $\left(\sigma_{s}^{2}\right)$, herd year $\left(\sigma_{h y}^{2}\right)$, residual $\left(\sigma_{e}^{2}\right)$, and total variances for SUV1 (survival from arrival to weaning) and SUV2 (survival from weaning to exit)

\begin{tabular}{lcccc}
\hline Trait & $\sigma_{s}^{2}$ & \multicolumn{1}{c}{$\sigma_{h y}^{2}$} & \multicolumn{1}{c}{$\sigma_{e}^{2}$} & \multicolumn{1}{c}{ Total } \\
\hline SUV1 & 0.0000009 & 0.0000009 & 0.005931 & 0.005932 \\
SUV2 & 0.0007028 & 0.0017254 & 0.0768616 & 0.0792898 \\
\hline
\end{tabular}

from 1 to $180 \mathrm{~d}$ of age (D1-180; Hansen et al., 2003). The heritability for this trait was much lower $(0.0072 \pm$ $0.1 \%$ ) than the findings of the current study. A more recent study also estimated genetic parameters of mortality in a population of Danish Holstein calves using a linear and threshold sire model (Fuerst-Waltl and $\mathbf{S} \varnothing-$ rensen, 2009). Similar to the current study, heritabilities for survival were lower $(<0.025)$ in early life $(1-180$ $\mathrm{d}$ of age) and increased (0.042) as a heifer matured (closer to first lactation) (Fuerst-Waltl and Sørensen, 2009). Riley et al. (2004) demonstrated a higher heritability estimate $(0.06 \pm 0.05)$ for preweaning mortality in Brahman calves). Mean preweaning heifer mortality, however, was $10 \%$ in the previously mentioned study, whereas that in the current study was only $2.7 \%$.

As mentioned earlier, pre- and postnatal mortality have been examined in Danish Holsteins, and were considered as 4 separate binary traits according to different periods of risk for death (in days) (Hansen et al., 2003). These traits were defined as D1-14, D15-60, D61-180, and D1-180. Direct heritabilities through D1-14 and D15-60 were $0.0029 \pm 0.0006$ and 0.0014 \pm 0.0004 , respectively. These 2 traits consider days of risk for mortality that overlap with the SUV1 trait in the current study. However, the heritability found was greater than that of the present study. Traits SUV2 and D61-180 also overlap days of risk for mortality between the 2 studies. Heritabilities of SUV2 (0.0355) and D61-180 (0.0077 \pm 0.0010$)$ are also not comparable. Although higher heritability was found for D1-14 and D15-60 compared with SUV1, lower heritability was found for D61-180 than for SUV2. These differences could be partly attributed to the fact that large differences in the distribution of mortality existed between the 2 studies. Most mortality occurred postweaning in the current study, whereas the majority of mortality

Table 3. Heritabilities (on diagonal) of SUV1 (survival from arrival to weaning) and SUV2 (survival from weaning to exit) and genetic (above diagonal) and residual (below diagonal) correlations (SE in parentheses)

\begin{tabular}{lcc}
\hline & SUV1 & SUV2 \\
\hline SUV1 & $0.0006(0.0026)$ & $0.5800(0.2672)$ \\
SUV2 & $0.1842(0.0162)$ & $0.0355(0.0039)$ \\
\hline
\end{tabular}

occurred in the first $14 \mathrm{~d}$ of life in the Danish study. In terms of genetic correlations, however, similarity between the 2 studies is evident. In the Danish Holstein population, the estimated genetic correlation was high (0.73) between D1-14 and D15-60, moderate (0.54) between D15-60 and D61-180, and low between D1-14 and D61-180 (Hansen et al., 2003). The current study found a genetic correlation of 0.58 between SUV1 and SUV2. Direct genetic correlations from both of these studies indicated that potentially different genes are responsible for early (SUV1, D1-14, D15-60) and late (SUV2, D61-180) postnatal mortality.

Estimated breeding values for all sires meeting the restriction criteria ( $\geq 10$ daughters; $n=246$ sires) were computed and standardized to a mean of 100 and SD of 5 for each of the survival traits. Minimum and maximum EBV were 87 and 116 and 83 and 113 for SUV1 and SUV2, respectively.

\section{Associations with Routinely Evaluated Traits in Canada and the United States}

Correlations between EBV of the 2 survival traits of interest and routinely evaluated Canadian and US traits were determined. All correlations found to be significant with EBV for routinely evaluated Canadian traits are presented in Table 4 and with PTA for routinely evaluated US traits are presented in Table 5. The trait SUV2 was significantly associated with more routinely evaluated traits than SUV1. Some of the associations of survival EBV with routinely evaluated common traits make biological sense and are logically plausible. On the other hand, the associations between survival and some routinely evaluated traits; for instance, udder conformation traits, age at first service, and daughter pregnancy rate, are more difficult to rationalize. It is possible that the size and robust nature of the current data set resulted in finding some associations that may be spurious. Nevertheless, further investigation of these associations is warranted.

Correlations among genetic evaluations for feet and leg traits, such as feet and leg composite and rear leg-rear view, were positively correlated with SUV2. Bone quality was positively correlated with SUV1. In addition, the PTA for the US trait rear leg-rear view was positively correlated with SUV2. The importance of desirable foot and leg conformation in cows is well recognized, because positive relationships between feet and legs and herd life have been shown in numerous studies (Foster et al., 1988; Boettcher et al., 1997; Sewalem et al., 2004). Additionally, many countries include some measure of feet and legs in their selection programs, often as a predictor of longevity (Cue et al., 1996; Vollema et al., 2000; Miglior et al., 2005). Desir- 
Table 4. Correlations between genetic evaluations for the 2 survival traits and traits routinely evaluated by Canadian Dairy Network (Guelph, ON, Canada)

\begin{tabular}{|c|c|c|c|c|c|}
\hline Routinely evaluated trait & $\begin{array}{l}\text { Sires } \\
(\mathrm{n})\end{array}$ & $\begin{array}{l}\text { Survival } \\
\text { to weaning }\end{array}$ & $P$-value & $\begin{array}{c}\text { Survival } \\
\text { after weaning }\end{array}$ & $P$-value \\
\hline \multicolumn{6}{|l|}{ Conformation } \\
\hline Feet and legs composite & 124 & - & - & 0.252 & 0.005 \\
\hline Bone quality & 124 & 0.189 & 0.036 & - & - \\
\hline Rear leg-rear view & 124 & - & - & 0.188 & 0.037 \\
\hline Dairy strength & 124 & - & - & -0.184 & 0.041 \\
\hline Stature & 124 & - & - & -0.187 & 0.038 \\
\hline Chest width & 124 & -0.303 & 0.001 & -0.271 & 0.002 \\
\hline Body depth & 124 & -0.193 & 0.032 & -0.194 & 0.031 \\
\hline Rump width & 124 & - & - & -0.191 & 0.033 \\
\hline Udder texture & 124 & 0.183 & 0.042 & - & - \\
\hline Rear udder attachment height & 124 & 0.178 & 0.048 & 0.202 & 0.024 \\
\hline Teat length & 124 & 0.289 & 0.001 & 0.290 & 0.001 \\
\hline \multicolumn{6}{|l|}{ Heifer reproduction } \\
\hline Age at first service & 128 & -0.258 & 0.003 & -0.191 & 0.031 \\
\hline Direct calf survival & 128 & - & - & 0.228 & 0.010 \\
\hline
\end{tabular}

able feet and leg conformation appears to have an effect on survival even as a calf and mature heifer, according to the associations revealed in the current analysis.

Dairy strength, stature, chest width, body depth, and rump width are routinely evaluated Canadian body conformation traits, which were all found to be negatively associated with one or both of the survival traits of interest. Dairy strength, stature, and rump width EBV were all negatively correlated with SUV2, whereas chest width and body depth were found to be negatively associated with both SUV1 and SUV2. Similarly, these associations existed between the survival traits of interest and routinely evaluated body traits in the United States. Stature and thurl width were negatively associated with SUV2, and strength and body depth were negatively associated with both SUV1 and SUV2. These associations indicate that calves sired by bulls with high genetic evaluations for linear body size conformation traits are less likely to survive to maturity than calves sired by bulls of lower genetic value for these traits. Heavy calves with large body dimensions are most likely sired by bulls with high EBV for body size, because these traits are highly heritable (Foster et al., 1988). The negative association of genetic evaluations for body conformation traits with calf and heifer survival may be due to the relationship between calf size and calving ease, with higher weight calves experiencing more dystocia (Sieber et al., 1989). Because of calving problems associated with higher birth weight calves, subsequent health problems persist beyond early life, influencing survival negatively.

The EBV for the Canadian trait "direct calf survival" in heifers was positively correlated with SUV2. Moreover, the US PTA for maternal calf survival was

Table 5. Correlations between genetic evaluations for the 2 survival traits and traits routinely evaluated by the USDA Animal Improvement Programs Laboratory (Beltsville, MD) and the Holstein Association USA (Brattleboro, VT)

\begin{tabular}{|c|c|c|c|c|c|}
\hline Routinely evaluated trait & $\begin{array}{l}\text { Sires } \\
(\mathrm{n})\end{array}$ & $\begin{array}{l}\text { Survival } \\
\text { to weaning }\end{array}$ & $P$-value & $\begin{array}{c}\text { Survival } \\
\text { after weaning }\end{array}$ & $P$-value \\
\hline \multicolumn{6}{|l|}{ Type } \\
\hline Teat length & 217 & - & - & 0.144 & 0.034 \\
\hline Rear legs-rear view & 217 & - & - & 0.141 & 0.038 \\
\hline Stature & 217 & - & - & -0.158 & 0.020 \\
\hline Strength & 217 & -0.164 & 0.015 & -0.179 & 0.008 \\
\hline Body depth & 217 & -0.156 & 0.022 & -0.203 & 0.003 \\
\hline Thurl width & 217 & - & - & -0.187 & 0.006 \\
\hline \multicolumn{6}{|l|}{ Udder health } \\
\hline SCS & 228 & -0.150 & 0.023 & -0.141 & 0.034 \\
\hline Fertility & & & & & \\
\hline $\begin{array}{l}\text { Daughter pregnancy rate } \\
\text { Calving traits }\end{array}$ & 221 & -0.152 & 0.023 & - & - \\
\hline $\begin{array}{l}\text { Maternal calf survival } \\
\text { Longevity }\end{array}$ & 210 & 0.155 & 0.024 & 0.155 & 0.024 \\
\hline Productive life & 212 & - & - & 0.133 & 0.053 \\
\hline
\end{tabular}


positively correlated with both SUV1 and SUV2. Direct calf survival (Canada) considers the first $24 \mathrm{~h}$ of life, whereas maternal calf survival (US) considers the first $48 \mathrm{~h}$ of life. The association between genetic evaluations for direct calf survival and SUV2 means that calves sired by bulls whose offspring are more likely to survive during the first $24 \mathrm{~h}$ of life are also more likely to survive to heifer maturity. From the maternal calf survival standpoint, the positive association between genetic evaluations for maternal calf survival and both SUV1 and SUV2 indicates that bulls siring dams whose calves are more likely to survive to maturity (the bull is the maternal grandsire of the calf) also sire calves more likely to survive to this time.

The EBV for SCS were negatively correlated with EBV for SUV1 and SUV2. In addition, the EBV for direct herd life was positively correlated with the EBV for SUV2. In terms of SCS, this association shows that bulls that sire daughters with low SCS also sire calves that are more likely to survive to maturity, suggesting that immune function is an influencing factor of survival. The association between EBV for direct herd life and EBV for the survival traits of interest, however, is opposite, yet still desirable. Direct herd life reflects true daughter survival corrected for production. It is measured using 5 traits (survival from first calving to 120 DIM, from 120 DIM to 240 DIM, from 240 DIM to second calving, from second calving to third calving, and from third calving to fourth calving (Sewalem et al., 2007). A positive correlation between EBV for direct herd life and SUV2, therefore, indicates that bulls that sire cows who live longer (therefore having a longer herd life) also sire calves who survive to maturity more so than bulls with lower EBV for direct herd life. The negative association observed between SCS and survival traits, as well as the positive association seen with direct herd life and the survival traits, might be an indicator of some general disease resistance factor with a genetic component (Heringstad et al., 2005). This association may enable cows sired by certain bulls to resist the occurrence of mastitis and, because of general increased immunity, survive longer than cows sired by other bulls poor for these traits. In this study, a linear model was used for the analysis of such data, which may not appropriate for analysis of binary data. However, the use of a linear model for a binary trait is considered a relatively robust approximation when the proportion of the distribution of the response variable is not too extreme. It might be of interest to compare the result of this analysis with an appropriate model suited for analysis of binary response data.

It is noteworthy that the results reported from the analysis were from a population of animals from a single, large heifer-raising facility in western New York
State. As such, extrapolation of these findings to the broader population of dairy calves should be done with caution.

\section{CONCLUSIONS}

This research has shown that genetic variance exists between sires for survival of calves after weaning through the growing period. Associations between EBV for SUV1 and SUV2 and routinely evaluated traits in Canada and the United States were found to be significant for several traits. Specifically, a large number of EBV and PTA for conformation traits were significantly correlated with the survival EBV. Although the heritabilities reported in the present study are low, genetic variability is sufficient for selection to be implemented, if recording of survival before first lactation is available on a large number of animals. Furthermore, calf and heifer survival traits add important economic value to the overall profitability of a dairy herd. It is clear that further investigation into a standardized method to record these traits on a national scale is warranted.

\section{ACKNOWLEDGMENTS}

The authors acknowledge the management and staff at CY Heifer Farm (Batavia, NY) for their invaluable contribution to this research. Funding was provided by the DairyGEN Council of the Canadian Dairy Network (Guelph, Ontario) and the National Science and Engineering Research Council of Canada (Ottawa, Ontario). Finally, the authors acknowledge the Animal Improvement Programs Laboratory (AIPL, USDA, Beltsville, MD) and the Holstein Association USA (Brattleboro, VT) for their kindness in allowing use of MACE PTA expressed on the US scale.

\section{REFERENCES}

Berger, P., J. Thompson, and C. Sattler. 1998. Preliminary investigations on the feasibility of a stillbirth evaluation for the USA. Interbull Bull. 18:28-30.

Boettcher, P. J., L. K. Jairath, K. R. Koots, and J. C. M. Dekkers. 1997. Effects of interactions between type and milk production on survival traits of Canadian Holsteins. J. Dairy Sci. 80:29842995.

Cue, R. I., B. L. Harris, and J. M. Rendel. 1996. Genetic parameters for traits other than production in purebred and crossbred New Zealand dairy cattle. Livest. Prod. Sci. 45:123-135.

Cundiff, L. V., M. D. MacNeil, K. E. Gregory, and R. M. Koch. 1986. Between- and within-breed genetic analysis of calving traits and survival to weaning in beef cattle. J. Anim. Sci. 63:27-33.

Curtis, C. R., H. N. Erb, and M. E. White. 1988. Descriptive epidemiology of calfhood morbidity and mortality in New York Holstein herds. Prev. Vet. Med. 5:293-307.

Donovan, G. A., I. R. Dohoo, D. M. Montgomery, and F. L. Bennett. 1998. Associations between passive immunity and morbidity and mortality in dairy heifers in Florida, USA. Prev. Vet. Med. 34:31-46. 
Ducrocq, V., and J. Sölkner. 1998. The survival kit, V3.12: A package for large analyses of survival data. Pages 447-450 in Proc. 6th World Congr. Genet. Appl. Livest. Prod., Armidale, Australia.

Erf, D. F., L. B. Hansen, and R. R. Neitzel. 1990. Inheritance of calf mortality for Brown Swiss cattle. J. Dairy Sci. 73:1130-1134.

Foster, W. W., A. E. Freeman, P. J. Berger, and A. Kuck. 1988. Linear type trait analysis with genetic parameter estimation. J. Dairy Sci. 71:223-231.

Fuerst-Waltl, B., and M. K. Sørensen. 2009. Genetic analysis of calf and heifer losses in Danish Holsteins. Proceedings of the Interbull Meeting in Barcelona, Spain. Interbull Bull. 40:117-171.

Gulliksen, S. M., K. I. Lie, T. Loken, and O. Osteras. 2009. Calf mortality in Norwegian dairy herds. J. Dairy Sci. 92:2782-2795.

Hansen, M., P. Madsen, J. Jensen, J. Pedersen, and L. G. Christensen. 2003. Genetic parameters of postnatal mortality in Danish Holstein calves. J. Dairy Sci. 86:1807-1817.

Heringstad, B., Y. M. Chang, D. Gianola, and G. Klemetsdal. 2005. Genetic analysis of clinical mastitis, milk fever, ketosis, and retained placenta in three lactations of Norwegian red cows. J. Dairy Sci. 88:3273-3281.

Heringstad, B., Y. M. Chang, D. Gianola, and O. Osteras. 2008. Short communication: Genetic analysis of respiratory disease in Norwegian red calves. J. Dairy Sci. 91:367-370.

Interbull. 2009. Interbull: National GES information. http://wwwinterbull.slu.se/national_ges_info2/framesida-ges.htm Accessed July 20, 2009.

Johanson, J. M., and P. J. Berger. 2003. Birth weight as a predictor of calving ease and perinatal mortality in Holstein cattle. J. Dairy Sci. 86:3745-3755.

Linden, T. C., R. C. Bicalho, and D. V. Nydam. 2009. Calf birth weight and its association with calf and cow survivability, disease incidence, reproductive performance, and milk production. J. Dairy Sci. 92:2580-2588.

Lombard, J. E., F. B. Garry, S. M. Tomlinson, and L. P. Garber. 2007. Impacts of dystocia on health and survival of dairy calves. J. Dairy Sci. 90:1751-1760.

Madsen, P., and J. A. Jensen, 2006. DMU, A package for analyzing multivariate mixed models. Version 6, release 4.6. Faculty of Agricultural Sciences (DJF), Department of Genetics and Biotechnology, Research Centre Foulum, Tjele, Denmark.

McGuire, T. C., N. E. Pfeiffer, J. M. Weikel, and R. C. Bartsch. 1976. Failure of colostral immunoglobulin transfer in calves dying from infectious disease. J. Am. Vet. Med. Assoc. 169:713-718.

Meyer, C. L., P. J. Berger, K. J. Koehler, J. R. Thompson, and C. G. Sattler. 2001. Phenotypic trends in incidence of stillbirth for Holsteins in the United States. J. Dairy Sci. 84:515-523.

Miglior, F., B. L. Muir, and B. J. Van Doormaal. 2005. Selection indices in Holstein cattle in various countries. J. Dairy Sci. 88:12551263.

NAHMS. 2007. Heifer and cow mortality. Page 3 in USDA APHIS:VS, Fort Collins, CO. http://nahms.aphis.usda.gov/dairy/dairy07/ Dairy07_ir_CalfHealth.pdf
Philipsson, J., J. L. Foulley, J. Lederer, T. Liboriussen, and A. Osinga. 1979. Sire evaluation standards and breeding strategies for limiting dystocia and stillbirth. report of an EEC/EAAP working group. Livest. Prod. Sci. 6:111-127.

Riley, D. G., C. C. Chase Jr., T. A. Olson, S. W. Coleman, and A. C. Hammond. 2004. Genetic and nongenetic influences on vigor at birth and preweaning mortality of purebred and high percentage Brahman calves. J. Anim. Sci. 82:1581-1588.

Robison, J. D., G. H. Stott, and S. K. DeNise. 1988. Effects of passive immunity on growth and survival in the dairy heifer. J. Dairy Sci $71: 1283-1287$

Sewalem, A., G. J. Kistemaker, F. Miglior, and B. J. Van Doormaal. 2004. Analysis of the relationship between type traits and functional survival in Canadian Holsteins using a Weibull proportional hazards model. J. Dairy Sci. 87:3938-3946.

Sewalem, A., F. Miglior, G. J. Kistemaker, P. Sullivan, G. Huapaya, and B. J. Van Doormaal. 2007. Short communication: Modification of genetic evaluation of herd life from a three-trait to a five-trait model in Canadian dairy cattle. J. Dairy Sci. 90:2025-2028.

Shook, G. E. 1989. Selection for disease resistance. J. Dairy Sci 72:1349-1362.

Sieber, M., A. E. Freeman, and D. H. Kelley. 1989. Effects of body measurements and weight on calf size and calving difficulty of Holsteins. J. Dairy Sci. 72:2402-2410.

Sivula, N. J., T. R. Ames, W. E. Marsh, and R. E. Werdin. 1996. Descriptive epidemiology of morbidity and mortality in Minnesota dairy heifer calves. Prev. Vet. Med. 27:155-171.

Svensson, C., A. Linder, and S.-O. Olsson. 2006. Mortality in Swedish dairy calves and replacement heifers. J. Dairy Sci. 89:47694777.

Van Amburgh, M. 2008. Early life management and long-term productivity in dairy calves. Page 1-8 in Dairy Health Management Certificate Program Proceedings, Guelph, ON, Canada. Ontario Veterinary College, Guelph, Ontario, Canada.

Vollema, A. R., S. Van Der Beek, A. G. F. Harbers, and G. De Jong. 2000. Genetic evaluation for longevity of Dutch dairy bulls. J. Dairy Sci. 83:2629-2639.

Waltner-Toews, D., S. W. Martin, and A. H. Meek. 1986. Dairy calf management, morbidity and mortality in Ontario Holstein herds. IV. Association of management with mortality. Prev. Vet. Med. 4:159-171.

Wells, S. J., D. A. Dargatz, and S. L. Ott. 1996. Factors associated with mortality to 21 days of life in dairy heifers in the United States. Prev. Vet. Med. 29:9-19.

Yazdi, M. H., P. M. Visscher, V. Ducrocq, and R. Thompson. 2002. Heritability, reliability of genetic evaluations and response to selection in proportional hazard models. J. Dairy Sci. 85:1563-1577. 